Economics Development Analysis Journal 7(3)(2018)

\title{
Strategi Penerbitan Obligasi Daerah Sebagai Alternatif Sumber Penerimaan Daerah di Provinsi Jawa Tengah
}

\author{
Ardita Dewi Yulianti ${ }^{\bowtie}$
}

Jurusan Ekonomi Pembangunan, Fakultas Ekonomi, Universitas Negeri Semarang

\begin{tabular}{|c|c|}
\hline Info Artikel & Abstrak \\
\hline $\begin{array}{l}\text { Sejarah Artikel: } \\
\text { Diterima April } 2017 \\
\text { Disetujui Juni } 2017 \\
\text { Dipublikasikan Agustus } \\
2017\end{array}$ & $\begin{array}{l}\text { Peraturan Menteri Keuangan No. 111/PMK.07 mengatur tentang tata cara penerbitan obligasi } \\
\text { daerah tetapi belum ada daerah yang menerbitkan termasuk Provinsi Jawa Tengah. Dilihat dari } \\
\text { tingkat solvabilitas dan likuiditas, Provinsi Jawa Tengah sudah memenuhi syarat penerbitan obligasi } \\
\text { daerah karena nilai dari DSCR telah memenuhi batas minimum yaitu sebesar } 2,54 \text { tetapi dari sisi } \\
\text { sumber daya manusia dirasa masih belum mampu. Tujuan dari penelitian ini adalah untuk } \\
\text { menganalisis relatif kemandirian keuangan Provinsi Jawa Tengah dibandingkan Provinsi lain serta } \\
\text { mengidentifikasi potensi dan peluang Provinsi Jawa tengah dalam penerbitan obligasi daerah serta } \\
\text { menganalisis strategi penerbitan obligasi Daerah di Provinsi Jawa Tengah. Sampel dalam penelitian } \\
\text { ini terdiri dari } 8 \text { keyperson. Adapun metode penelitian yang digunakan adalah analisis deskriptif } \\
\text { untuk mengetahui relatif kemandirian keuangan daerah, potensi dan peluang penerbitan obligasinya } \\
\text { dan Analisis Hierarki Proses (AHP) untuk menentukan strategi yang digunakan dalam prioritas } \\
\text { penerbitan obligasi daerah. Hasil penelitian menunjukkan bahwa permasalahan mendasar yang } \\
\text { dihadapi adalah masih terbatasnya sumber daya manusia yang terampil. Prioritas utama adalah } \\
\text { sumber daya manusia, yangkedua adalah kemandirian keuangan daerah, dan yang terakhir adalah } \\
\text { kemampuan keuangan daerah. }\end{array}$ \\
\hline
\end{tabular}

\begin{abstract}
Minister of Finance Regulation No. 111/PMK.07 set the procedures for published bonds, however the factis none of regions have successfully published it. Seen from the level of solvency and liquidity, Central JavaProvince had already qualified for issuance of municipals bonds has reached 2.54 DSCR value but in terms of human resources it still not able. The suggestion of this study is government and related sides are expected to applythe policy based on the result of this study. Then, the government and related sides have to focus on thepublication priority of region bond through training in reporting financial accounting of region government accordingto standard accounting of central government's financial report. There were eight key persons as sample in this study. The methods used in this study were descriptive analysis used to know the relative region financial independent, potential and opportunity in publishing bond and hierarchy process analysis (AHP) used to determine strategy in publication priority of region bond. The finding of this study shows that thebasicproblem is the limited skilled of human resource. The main priorities in publishing region bond in CentralJavaProvince are criteria region financial independent, criteria of region financial capability, and criteria human resource.
\end{abstract}




\section{PENDAHULUAN}

Obligasi daerah merupakan surat utang yang diterbitkan oleh Pemerintah Daerah yang ditawarkan kepada publik melalui penawaran umum di pasar modal. Di Indonesia, wacana mengenai diterbitkannya obligasi daerah sudah terdengar dari tahun 2000 bahkan undangundang untuk mengaturnya juga sudah dibuat tetapi sampai dengan tahun ini belum ada satu daerah yang menerbitkan obligasi daerah. Pro dan kontra terhadap rencana kebijakdan adaya obligasi daerah tetap terjadi meskipun banyak keuntungan yang akan didapatkan jika menerapkan obligasi di Indonesia. Obligasi sepenuhnya menjadi tanggung jawab Pemerintah Daerah dengan tetap berada dibawah pengawasan Pemerintah Pusat. Hal ini memicu ketidakpercayaan terhadap daerah untuk melakukan obligasi daerah karena daerah dianggap belum mampu untuk menerbitkan obligasi daerah.

Daerah juga dianggap belum mampu untuk penyusunan laporan keuangan seperti di Pemerintah Pusat. Dalam penerbtan obligasi daerah juga dirasa rumit dan panjang yang dituangkan dalam Peraturan Menteri Keuangan No. 111/PMK.07 Tahun 2012 Tentang Tata Cara Penerbitan dan Pertanggungjawaban Obligasi Daerah. Prosedur penerbitan obligasi daerah dimulai dari penentuan kegiatan, melaksanakan kegiatan persiapan, mengajukan persetujuan DPRD, mengajukan usulan penerbitan kepada menteri keuangan, pembuatan perda dan penawaran umum di pasar modal serta pengelolaan obligasi daerah. Dalam prosedur penerbitan obligasi daerah memang melibatkan Pemerintah Pusat dan daerah serta harus memenuhi beberapa persyaratan dalam aturan pasar modal. Hal inilah yang memberikan kesan bahwa penerbitan obligasi daerah rumit dan panjang.

Menurut Undang-Undang Nomor 33 Tahun 2004 tentang Perimbangan Keuangan antara Pemerintah Pusat dan Pemerintah Daerah, syarat penerbitan obligasi daerah juga harus memenuhi jumlah sisa pinjaman daerah ditambah dengan jumlah pinjaman yang akan ditarik tidak boleh melebihi $75 \%$ dari jumlah penerimaan umum APBD tahun sebelumnya. Syarat lainnya adalah memenuhi rasio kemampuan keuangan daerah untuk mengembalikan pinjaman (Debt Service Coverage Ratio) yang ditetapkan oleh Pemerintah Pusat yaitu tidak boleh melebihi 2,5 dengan memperhatikan perkembangan perekonomian nasional dan kapasitas fiskal daerah.

Daerah juga harus memenuhi peraturan perundang-undangan mengenai pinjaman daerah. Hal lain yang harus dipenuhi Pemerintah Daerah dalam penerbitan obligasi daerah adalah kemandirian keuangan daerah itu sendiri. Kemandirian keuangan daerah menunjukkan kemampuan Pemerintah Daerah dalam membiayai kegiatan pemerintahan, pembangunan dan pelayanan kepada masyarakat yang telah membayar pajak dan retribusi sebagai sumber yang diperlukan daerah (Halim, 2007:232). Tujuan dari penelitian ini adalah untuk menganalisis relatif kemandirian keuangan Provinsi Jawa Tengah dibandingkan Provinsi lain serta mengidentifikasi potensi dan peluang Provinsi Jawa Tengah dalam penerbitan obligasi daerah serta menganalisis strategi penerbitan obligasi daerah di Provinsi Jawa Tengah.

\section{METODE PENELITIAN}

Jenis penelitian yang digunakan dalam penelitian ini adalah jenis penelitian kualitatif dengan menggunakan metode analisis deskriptif dan Analisis Hierarki Proses (AHP). Metode analisis deskriptif digunakan untuk mengetahui permasalaha pada penerbitan obligasi daerah melalui kemandirian keuangan Provinsi Jawa Tengah serta potensi dan peluang Provinsi Jawa Tengah dalam penerbitan obligasi daerah. Sedangkan, Analisis Hierarki Proses (AHP) untuk mengetahui strategi yang harus dilakukan dalam rangka penerbitan obligasi daerah sebagai alternatif sumber penerimaan daerah di Provinsi Jawa Tengah.

Sumber data yang digunakan dalam penelitian ini berasal dari: (1) Data Primer 
diperoleh dari hasil wawancara dan kuesioner AHP, (2) Data Sekunder diperoleh dari dokumen publikasi atau laporan penelitian dari dinas atau instansi maupun sumber data lainnya yang menunjang.

Data primer diperoleh dari narasumber yang merupakan unsur pemerintah berjumlah 8 orang dengan melakukan wawancara. Selain itu, data primer juga diperoleh dari keyperson untuk perumusan kebijakan dalam Analisis Hierarki Proses (AHP) yang diperoleh juga dari unsur pemerintah BPKAD Provinsi Jawa Tengah dan Badan Perencanaan Pembangunan Daerah Provinsi Jawa Tengah dengan menggunakan angket atau kuesioner AHP. Keyperson tersebut ditentukan berdasarkan kriteria kepakaran dan keterlibatannya dalam upaya penerbitan obligasi daerah.

\section{HASIL DAN PEMB AHASAN}

Kemandirian Keuangan Provinsi Jawa Tengah dibandingkan dengan Provinsi lain yang ada di Pulau Jawa, kemandirian keuangan daerah dapat dilihat dari besarnya PAD dibandingkan dengan total pendapatan. Kemandirian keuangan daerah Provinsi Jawa Tengah dibandingkan dengan Provinsi lain yang ada di Pulau Jawa seperti pada tabel berikut ini:

Tabel 1. Kemandirian Keuangan Daerah $(\%)$

\begin{tabular}{lllll}
\hline Tahun & $\begin{array}{l}\text { DKI } \\
\text { Jakarta }\end{array}$ & $\begin{array}{l}\text { Jawa } \\
\text { Barat }\end{array}$ & $\begin{array}{l}\text { Jawa } \\
\text { Tengah }\end{array}$ & $\begin{array}{l}\text { Jawa } \\
\text { Timur }\end{array}$ \\
\hline 2010 & 56 & 75 & 72 & 74 \\
2011 & 62 & 77 & 74 & 77 \\
2012 & 62 & 59 & 57 & 62 \\
2013 & 68 & 64 & 62 & 64 \\
2014 & 71 & 67 & 65 & 70
\end{tabular}

Sumber: Direktorat Jenderal Perimbangan Keuangan, 2016.

Potensi dan Peluang Provinsi Jawa Tengah dalam Penerbitan Obligasi Daerah, ketentuan yang harus dipenuhi oleh suatu daerah untuk dapat melakukan pinjaman berdasarkan Peraturan Pemerintah Nomor 30 Tahun 2011 Tentang Pinjaman Daerah dan Peraturan Pemerintah Nomor 23 Tahun 2003 Tentang
Pengendalian Jumlah Kumulatif Defisit APBN dan APBD serta Jumlah Kumulatif Pinjaman Pemerintah Pusat dan Pemerintah Daerah menyebutkan bahwa jumlah kumulatif pokok pinjaman daerah yang wajib dibayar tidak melebihi dari jumlah Penerimaan Umum Anggaran Pendapatan Belanja Daerah tahun sebelumnya. Selain itu, berdasarkan proyeksi penerimaan dan pengeluaran daerah tahunan, dalam jangka waktu pinjaman Debt Service Couverage Ratio (DSCR) paling sedikit adalah 2,5.

Pengukuran tingkat solvabilitas dilakukan untuk melihat indikator yang menunjukkan kemampuan Pemerintah Daerah dalam melakukan pinjaman tambahan. Nilai batas maksimum pinjaman ditentukan tidak boleh melebihi 75\% dari Penerimaan Umum APBD. Dalam penelitian ini batas maksimum pinjaman didasarkan pada APBD Provinsi Jawa Tengah tahun 2010-2014 yang secara rinci dapat dilihat pada tabel berikut:

Tabel 2. Batas Maksimum Pinjaman Pemerintah Provinsi Jawa Tengah Tahun 20102014

\begin{tabular}{llll}
\hline Tahun & PU APBD & $\begin{array}{l}\text { Batas } \\
\text { Maksi } \\
\text { mum }\end{array}$ & BMPK \\
\hline 2010 & 7.543 .415 & 0,75 & 5.657 .561$, \\
& & & 25 \\
2011 & 8.850 .468 & 0,75 & 6.637 .851 \\
2012 & 9.740 .385 & 0,75 & 7.305 .288$, \\
& & & 75 \\
2013 & 10.546 .576 & 0,75 & 7.909 .932 \\
2014 & 11.019 .280 & 0,75 & 8.264 .460 \\
\hline Sumber: & Data Pengolahan Hasil Penelitian \\
(2017) & \multicolumn{3}{c}{}
\end{tabular}

Pengukuran tingkat likuiditas menunjukkan tingkat kemampuan Pemerintah Daerah Provinsi Jawa Tengah untuk membayar hutangnya yang telah jatuh tempo. Pengukuran tingkat likuiditas dapat menggunakan Debt Service Couverage Ratio (DSCR). Nilai dari Debt Service Couverage Ratio (DSCR) digunakan untuk mengetahui kemampuan suatu daerah dalam membayar cicilan pokok dan bunga atas pinjaman yang telah dilakukan termasuk atas 
penerbitan obligasi daerah. Nilai minimum DSCR berdasarkan Peraturan Pemerinah Nomor 30 Tahun 2011 sebesar 2,5 dengan memperhatikan perkembangan perekonomian nasional dan kapasitas fiskal daerah.

Asumsi yang digunakan untuk menghitung nilai DSCR Pemerintah Provinsi Jawa Tengah adalah nilai nominal adalah nilai batas maksimum Pemerintah Daerah dapat melakukan pinjaman seperti yang tertera pada tabel 4.3 di atas dan untuk jangka waktu tempo yang ditetapkan adalah selama 25 tahun serta tingkat suku bunga sebesar 11,5\% melihat dari pergerakan yield Surat Utang Negara tahun 2015. Selain itu, tidak terjadi perubahan peraturan perundang-undangan khususnya yang berkaitan dengan keuangan daerah serta penerbitan obligasi harus melalui pasar modal. Penghitungan Debt Service Couverage Ratio (DSCR) Pemerintah Provinsi Jawa Tengah secara rinci sebagai berikut.

Tabel 3. Penghitungan DSCR Provinsi Jawa Tengah Tahun 2010-2014

(dalam jutaan rupiah untuk penghitungan obligasi daerah)

\begin{tabular}{lllll}
\hline Tahun & $\begin{array}{l}\text { Nominal } \\
\text { Obligasi }\end{array}$ & $\begin{array}{l}\text { Suku } \\
\text { Bunga }\end{array}$ & $\begin{array}{l}\text { Jatuh } \\
\text { Tempo }\end{array}$ & DSCR \\
\hline 2010 & 5.657 .561$, & $10,79 \%$ & 25 & 1,44766 \\
& 25 & & tahun & 623 \\
2011 & 6.637 .851 & $10,94 \%$ & 25 & 1,55925 \\
& & & tahun & 395 \\
2012 & 7.305 .288$, & $11,48 \%$ & 25 & 1,99515 \\
& 75 & & tahun & 851 \\
2013 & 7.909 .932 & $11,91 \%$ & 25 & 2,17101 \\
& & & tahun & 128 \\
2014 & 8.264 .460 & $12,42 \%$ & 25 & 2,54150 \\
& & & tahun & 945 \\
\hline Sumber & :Data & Pengolahan & Hasil & Penelitian \\
$(2017)$ & & & &
\end{tabular}

Berdasarkan hasil penghitungan Debt service Couverage Ratio (DSCR) di atas, dari tahun 2010 sampai 2013 Provinsi Jawa Tengah tidak layak untuk menerbitkan obligasi daerah karena nilai dari Debt Service Couverage Ratio (DSCR) tidak memenuhi nilai minimum yang telah ditetapkan yaitu sebesar 2,5. Pada tahun 2010 nilai dari Debt Service Couverage Ratio (DSCR) hanya sebesar 1,4 tetapi pada tahun 2011 mengalami peningkatan sebesar 1,5. Pada tahun 2012 nilai dari Debt Service Couverage Ratio (DSCR) meningkat menjadi 2 dan tahun 2013 nilai Debt Service Couverage Ratio (DSCR) kembali meningkat menjadi 2,2. Sehingga dari tahun 2010 sampai dengan tahun 2013 Provinsi Jawa Tengah belum bisa menerbitkan obligasi daerah karena belum memenuhi standar minimum.

Sementara itu, hasil penghitungan Debt Service Couverage Ratio (DSCR) Pemerintah Daerah Provinsi Jawa Tengah sudah memenuhi syarat penerbitan dari tingkat likuiditasnya karena nilai dari Debt Service Couverage Ratio (DSCR) minimum yang telah disyaratkan oleh Peraturan Pemerintah Nomor 30 Tahun 2011 Tentang Pinjaman Daerah yaitu sebesar 2,5 dapat terpenuhi. Pada tahun 2014, nilai DSCR Provinsi Jawa Tengah sebesar 2,54.

Asumsi yang digunakan untuk menghitung Debt Service Couverage Ratio (DSCR) atas penerbitan obligasi daerah ini yaitu nilai nominal obligasi daerah didasarkan nilai batas maksimum pinjaman, suku bunga pada tahun 2010 sebesar 10,79\%, 2011 sebesar 10,94\%, 2012 sebesar 11,48\%, 2013 sebesar 11,91\%, 2014 sebesar $12,42 \%$ melihat pergerakan yield SUN dan jangka waktu jatuh tempo obligasi daerah selama 25 tahun.

Strategi Penerbitan Obligasi Daerah di Provinsi Jawa Tengah, program penerbitan obligasi daerah di Provinsi Jawa engah terkait dengan beberapa aspek utama antara lain: aspek kemandirian keuangan daerah, aspek kemampuan keuangan daerah, dan aspek sumber daya manusia.

Berdasarkan pendapat gabungan para keyperson menunjukkan bahwa aspek sumber daya manusia (nilai bobot 0,427 ) merupakan kriteria paling penting yang perlu diperhatikan dalam upaya penerbitan obligasi daerah. Aspek berikutnya yang perlu diperhatikan adalah aspek kemandirian keuangan daerah (nilai bobot 0,383). Aspek kemampuan keuangan daerah (nilai bobot 0,191). Nilai inconsistency ratio $0,01<0,1$ (batas maksimum) yang berarti bahwa hasil analisis tersebut dapat diterima. 
Tab el 3. Kriteria Penerbitan Obligasi

\begin{tabular}{llll}
\multicolumn{3}{c}{ Daerah } \\
\hline No & Program & $\begin{array}{l}\text { Nilai } \\
\text { Bobot }\end{array}$ & Keterangan \\
\hline 1. & $\begin{array}{l}\text { Kemandirian } \\
\text { Keuangan } \\
\text { Daerah }\end{array}$ & 0,383 & $\begin{array}{l}\text { Inconsistency } \\
\text { Ratio }=0,01\end{array}$ \\
2. & $\begin{array}{l}\text { Kemampuan } \\
\text { Keuangan } \\
\text { Daerah } \\
\text { 3. } 0,191\end{array}$ & \\
& $\begin{array}{l}\text { Sumber Daya } \\
\text { Manusia }\end{array}$ & & \\
\hline
\end{tabular}

Sumber: Data Primer, diolah (2017)

Terpilihnya aspek sumber daya manusia sebagai prioritas utama yang harus diperhatikan dalam upaya penerbitan obligasi daerah mencerminkan bahwa tingkat kemampuan sumber daya manusia pada instansi pemerintahan yang mengerti masalah obligasi daerah sangat erat kaitannya dengan program penerbitan obligasi daerah sebagai alternatif sumber peerimaan daerah di Provinsi Jawa Tengah.

Aspek Sumber Daya Manusia, krieria pertama yang menjadi prioritas dalam penerbitan obligasi daerah sebagai alternatif sumber penerimaan daerah di Provinsi Jawa Tengah adalah kriteria sumber daya manusia.

Tabel 4. Kriteria Sumber Daya Manusia

\begin{tabular}{lll}
\hline $\begin{array}{l}\text { Kriteria Sumber } \\
\text { Daya Manusia }\end{array}$ & $\begin{array}{l}\text { Nilai } \\
\text { Bobot }\end{array}$ & Keterangan \\
\hline $\begin{array}{l}\text { Pemilihan sumber } \\
\text { daya manusia yang }\end{array}$ & 0,178 & $\begin{array}{l}\text { Inconsistency } \\
\text { Ratio }=0,05\end{array}$ \\
kompeten di bidang & & \\
obligasi daerah & & \\
Pelatihan pelaporan & 0,678 & \\
keuangan yang & & \\
menganut standar & & \\
akuntani pelaporan \\
keuangan pusat \\
Membentuk badan \\
atau lembaga yang \\
mengurusi tentang \\
obligasi daerah
\end{tabular}

Sumber: Data Primer, diolah (2017)
Berdasarkan hasil pengolahan penelitian di atas dapat diketahui bahwa pelatihan pelaporan keuangan yang menganut standar akuntasi keuangan pusat merupakan alternatif yang paling menjadi prioritas dalam penerbitan obligasi daerah dari aspek sumber daya manusia dengan persentase prioritas sebesar 67,8\%. Selanjutnya yang menjadi prioritas kedua adalah pemilihan sumber daya manusia yang kompeten dibidang obligasi daerah dengan persentase prioritas sebsar $17,8 \%$. Prioritas yang terakhir adalah membentuk badan atau lembaga sendiri yang mengurusi tentang obligasi daerah dengan persentase prioritas sebsar $14,2 \%$. Nilai dari inconsistency ratio $0,05<0,1$ (batas maksimum) yang berarti hasil dari analisis tersebut dapat diterima.

Aspek Kemandirian Keuangan Daerah, aspek kedua dalam strategi penerbitan obligasi daerah senagai alternatif sumber penerimaan daerah di Provinsi Jawa Tengah adalah aspek kemandirian keuangan daerah.

Tabel 5. Kriteria Kemampuan Keuangan Daerah

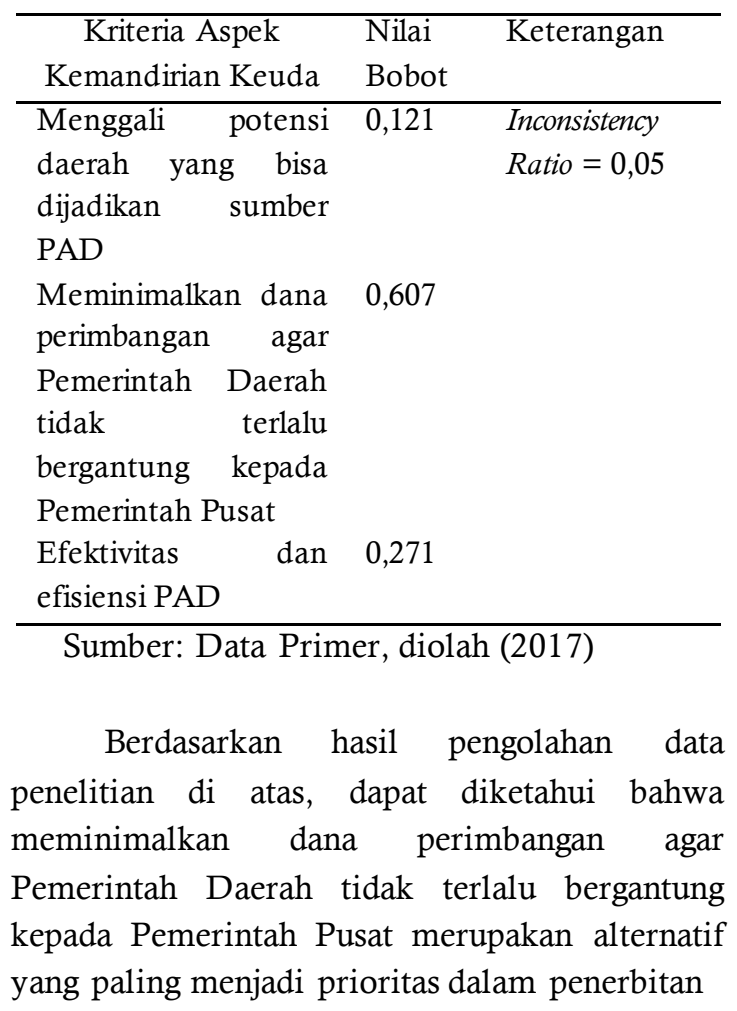


obligasi daerah dari aspek kemandirian keuangan daerah dengan persentase prioritas sebesar $60,7 \%$. Selanjutnya yang menjadi prioritas kedua untuk menerbitkan obligasi daerah adalah efektivias dan efisiensi Pendapatan Asli Daerah (PAD) dengan persentase prioritas sebesar $27,1 \%$. Prioritas yang terakhir adalah menggali potensi daerah yang bisa dijadikan sumber Pendapatan Asli Daerah (PAD) dengan persentase prioritas sebesar $12,1 \%$. Nilai inconsistency ratio $0.05<0,1$ (batas maksimum) yang berarti hasil dari analisis tersebut dapat diterima. Dari hasil tersebut didapat urutan alternatif strategi yang perlu dilakukan agar penerbitan obligasi daerah sebaai alternatif sumber penerimaan daerah di Provinsi Jawa Tengah dari aspek kemandirian keuangan daerah.

Aspek Kemampuan Keuangan Daerah, aspek terakhir yang perlu dipertimbangkan dalam penerbitan obligasi daerah sebagai alternatif sumber penerimaan daerah di Provinsi Jawa Tengah adalah aspek kemampuan keuangan daerah.

Tabel 6. Kriteria Kemampuan Keuangan Daerah

\begin{tabular}{llll}
\hline No. & $\begin{array}{l}\text { Kriteria } \\
\text { Kemampuan }\end{array}$ & $\begin{array}{l}\text { Nilai } \\
\text { Bobot }\end{array}$ & Keterangan \\
& Keuda & & \\
\hline $1 . \quad$ & $\begin{array}{l}\text { Efektivitas dan } \\
\text { efisiensi belanja }\end{array}$ & 0,438 & $\begin{array}{l}\text { Inconsistency } \\
\text { Ratio }=0,01\end{array}$ \\
daerah & & \\
Optimalisasi & 0.086 & \\
& $\begin{array}{l}\text { pajak daerah } \\
\text { dan retrbusi } \\
\text { daerah } \\
\text { Profesionalitas } \\
\text { perusahaan } \\
\text { daerah yang }\end{array}$ \\
& & \\
sudah ada & & \\
\end{tabular}

Sumber: Data Primer, diolah (2017)

Berdasarkan hasil pengolahan data penelitian di atas dapat diketahui bahwa profesionalitas perusahaan daerah yang sudah ada merupakan alternatif yang menjadi prioritas dalam penerbitan obligasi daerah di Provinsi Jawa Tengah dari aspek kemampuan keuangan daerah dengan persentase prioritas sebesar 47,6\%. Selanjutnya yang menjadi prioritas kedua untuk penerbitan obligasi daerah di Provinsi Jawa Tengah adalah efektivitas dan efisiensi belanja daerah dengan persentase prioritas sebesar 43,8\%. Prioritas terakhir adalah optimalisasi pajak daerah dan retribusi daerah dengan perentase prioritas sebesar 0,086\%. Nilai inconsistency ratio 0,01 $<0,1$ (batas maksimum) yang berarti hasil analisis tersebut dapat diterima. Implikasi penting dari hal tersebut adalah perlu adanya profesionalitas dari perusahaa-perusahaan daerah yang sudah ada. Banyak perusahaan daerah di Provinsi Jawa Tengah yang tidak memiliki profesionalitas sebagai perusahaan daerah

\section{SIMPULAN}

Kemandirian keuangan daerah Provinsi Jawa Tengah dibanding Provinsi yang ada di Pulau Jawa lainnya cenderung stabil bahkan dari tahun 2010 hingga 2014 mengalami peningkatan. Hal ini sangat baik karena daerah yang ingin menerbitkan obligasi daerah harus memiliki kemandirian keuangan daerah. Provinsi Jawa Tengah mempunyai potensi dan peluang dalam penerbitan obligasi daerah karena pada tahun 2014 telah memenuhi syarat penerbitan obligasi daerah dari sisi tingkat solvabilitas dan likuiditas sebesar 2,54 yang berarti telah memenuhi standar minimum Debt Service Couverage Ratio (DSCR) yaitu sebsar 2,5. Meskipun Provinsi Jawa Tengah telah memenuhi syarat tingkat solvabilitas dan likuiditas karena dapat memenuhi persyaratan penerbitan obligasi daerah, namun sampai saat ini Provinsi Jawa Tengah belum mempunyai keberanian untuk menerbitkan obligasi daerah. Provinsi Jawa Tengah diras belum mempunyai kesiapan dalam sumber daya manusia jika obligasi daerah benarbenar diterapkan. Padahal Provinsi Jawa Tengah memiliki banyak proyek-proyek besar yang akan sangat menguntungkan jika dibiatai dengan obligasi daerah karena akan mendatangkan manfaat bagi daerah.

Strategi penerbitan obligasi daerah melalui AHP yang dilakukan terhadap 8 keyperson yang 
terdiri dari unsur pemerintahan menunjukkan bahwa aspek kemandirian keuangan daerah $(0,491)$ merupakan aspek yang paling penting yang perlu diperhatikan dalam strategi penerbitan obligasi daerah sebagai alternatif sumber penerimaan daerah di Provinsi Jawa Tengah. Aspek berikutnya adalah aspek kemampuan keuangan daerah $(0,276)$ dan aspek sumber daya manusia (0,233). Sedangkan kriteria dan alternatif secara keseluruhan (overall) yang menjadi prioritas penerbitan obligasi daerah dilakukan dengan melakukan pelatihan pelaporan keuangan yang menganut standar akuntansi keuangan pelaporan Pemerintah Pusat, meminimalkan dana perimbangan agar Pemerintah Daerah tidak terlalu bergantung kepada Pemerintah Pusat, serta meningkatkan profesionalitas perusahaan daerah yang sudah ada.

Kemandirian keuangan Provinsi Jawa Tengah sudah baik dan stabil hanya perlu dipertahankan dan ditingkatkan agar kemandirian keuangan Provinsi Jawa Tengah dapat terus stabil, Potensi dan peluang penerbitan obligasi daerah Provinsi Jawa Tengah dari sisi tingkat likuiditas dan solvabilitas sudah terpenuhi tetapi untuk sumber daya manusia yang dimiliki masih belum siap sehingga perlu banyak dilakukan upaya peningkatan kemampuan sumber daya manusianya, Pemerintah Daerah Provinsi Jawa Tengah disarankan untuk lebih banyak mengadakan pelatihan pelaporan keuangan karena tidak semua instansi pemerintahan sudah menganut standar akuntansi keuangan pusat. Hal ini dilakukan agar pelaporan keuangan Pemerintah Daerah menganut standar akuntansi keuangan Pemerintah Pusat. Daerah juga sebaiknya mulai meminimalkan dana perimbangan agar tidak terlalu bergantung kepada Pemerintah Pusat. Selain itu, profesionalitas perusahaan daerah juga harus diperbaiki agar memenuhi kewajibannya karena pada intinya pembentukan perusahaan daerah diharapkan mampu memeberikan sumbangan bagi daerah atau turut berkontribusi untuk pembangunan daerah agar pembangunan di daerah dapat terus berjalan.

\section{DAFTAR PUSTAKA}

Anggiasari, Ni Made. 2016. Sikap dan Pengambilan Keputusan Pembelian Sayuran Organik Oleh Konsumen di Kota Bandar Lampung. Skripsi. Bandar Lampung. Universitas Lampung.

B.N. Marbun. 2003. Kamus Manajemen. Jakarta: Pustaka Sinar Harapan.

Cahyadin, Malik dan Dora Indriana. 2005. "Kemungkinan Penerbitan Obligasi Daerah: Studi Kasus Pemerintah Daerah di Provinsi Jawa Timur". Dalam Simposium Riset Ekonomi II. Surabaya: Ikatan Sarjana Ekonomi Indonesia.

Dirjen Perimbangan Keauangan. 2010-2014. Data Keuangan Daerah Tahun 2010-2014. Dirjen Perimbangan Keuangan. Jakarta: Kementrian Keuangan.

Badan Pusat Statistik. 2010-2014. Jawa Tengah Dalam Angka 2010-2014. Badan Pusat Statistik Provinsi Jawa Tengah. Semarang: Badan Pusat Statistik..

Hadi, Sasana. 2009. Peran Desentralisasi Fiskal Terhadap Kinerja Ekonomi di Kabupaten/Kota Propinsi Jawa Tengah. Jurnal Ekonomi Pembangunan Vol.10 (1) Juni.

Halim, Abdul. 2007. Akuntansi Keuangan Daerah. Buku Edisi Ketiga. Jakarta: Penerbit Salemba Penerbit Yogyakarta.

Halim, Abdul. 2008. Akuntansi Keuangan Daerah. Jakarta: Salemba Empat

Halim, Abdul. 2009. Problem Desentralisasi dan Perimbangan Keuanagan Pemerintah PusatDaerah: Peluang dan Tantangan dalam Pengelolaan Sumber Daya Daerah. Yogyakarta. Sekolah Pascasarjana UGM.

Halim, Abdu1.2014. Manajemen Keuangan Sektor Publik. Jakarta. Salemba Empat.

Hardjana, M. Agus. 2001. Training SDM Yang Efektif. Yogyakarta: Kanisius.

Mahardika, I Gusti Ngurah Suryaadi dan Luh Gede Sri Artini. 2012. Analisis Kemandirian Keuangan Daerah di Era Otonomi Pada Pemerintah Kabupaten Tabanan. Denpasar. Universitas Udayana.

Moleong, Lexy J. 2004. Metodologi Penelitian Kualitatif. Bandung: PT. Remaja Rosdakarya.

Mulyadi. S. 2003. Ekonomi Sumber Daya Manusia dalam Perspektif Pembangunan. Jakarta: Raja Grafindo.

Muzakki, Iko Taufik. 2012. Analisis Perbandingan Kinerja Perusahaan yang Menerbitkan Obligasi Daerah dengan Perusahaan yang 
Menerbitkan Obligasi Konvensional. Skripsi. Yogyakarta. Universitas Islam Negeri Sunan Kalijaga

Okta, Dewi dan David Kaluge. 2011. "Analisis Peluang Penerbitan Obligasi Daerah Sebagai Alternatif Pembiayaan Daerah". Journal of Indonesian Applied Economics. Vol.5, No.2, October, 2011, Hal. 157-171.

Pambudi, Hasan. 1981. Dasar dan Teknik Penerbitan Buku. Jakarta. Sinar Harapan Tersedia.

Peraturan Menteri Keuangan Republik Indonesia Nomor 111/PMK.07 Tahun 2012 Tentang Tata Cara Penerbitan dan Pertanggungjawaban Obligasi Daerah, 2016. Jakarta.

Peraturan Pemerintah Republik Indonesia Nomor 30 Tahun 2011 Tentang Pinjaman Daerah, 2016. Jakarta.

Peraturan Pemerintah Nomor 23 Tahun 2003 Tentang Pengendalian Jumlah Kumulatif APBN dan APBD serta Jumlah Kumulatif Pinjaman Pemerintah Pusat dan Pemerintah Daerah, 2016. Jakarta.

Prasetya, Devi. 2008. Analisis Perbedaan Kinerja Perusahaan Sebelum dan Setelah Penerbitan Obligasi Syariah di Indonesia Periode Penelitian 2003-2007. Skripsi. Depok. Universitas Indonesia.

Rangkuti, Freddy. 2008. Analisis SWOT Teknik Membedah Kasus Bisnis. Jakarta: PT. Gramedia Pustaka Utama.

Richard L. Daft. 2010. Era Baru Manajemen. Edisi 9: Salemba Empat.
Simanjuntak, Payaman J. 2001. Pengantar Ekonomi Sumber Daya Manusia. Jakarta: Lembaga Penerbit Fakultas Ekonomi Universitas Indonesia.

Sucihatiningsih, DWP. 2013. Metode Analisis Efisiensi Produksi dan Pengambilan Keputusan Bidang Ekonomi Pertanian. Semarang: Unnes Press.

Sugiyono, 2014. Memahami Penelitian Kualitatif. Bandung. Alfabeta

Suryani, Irma. 2009. Analisis Strategi Peningkatan Pendapatan Retribusi Pasar di Kabupaten Pekalongan. Skripsi. Semarang. Universitas Diponegoro.

S. Purnomo, Budi. 2006. "Obligasi Daerah Sebagai Alternatif Pembiayaan Pembangunan Daerah di Indonesia". Dalam Jurnal Prosiding Kopertis Wilayah IV. Vol.2, No.1, April, 2006.

Undang-Undang Republik Indonesia Nomor 33 Tahun 2004 Tentang Perimbangan Keuangan Antara Pemerintah Pusat dan Pemerintah Daerah, 2016. Jakarta.

Undang-Undang Republik Indonesia Nomor 23 Tahun 2014 Tentang Pemerintahan Daerah, 2016. Jakarta.

Widjajani dan Dede Siti Rohmah. 2013. "Model Perilaku Strategis Pengusaha Industri Kecil Dalam Membangun Keuanggulan Kompetitif (Studi Kasus Pengusaha Batik Tasikmalaya)". Media Riset Bsnis dan Manajemen, Vol. 13, No.1, April 2013 pp. 62-75. 